\title{
前立腺肥大症に抢ける経直腸的超音波断層法と尿道内圧曲線の
}

比較検討，ならびに尿水力学的評価

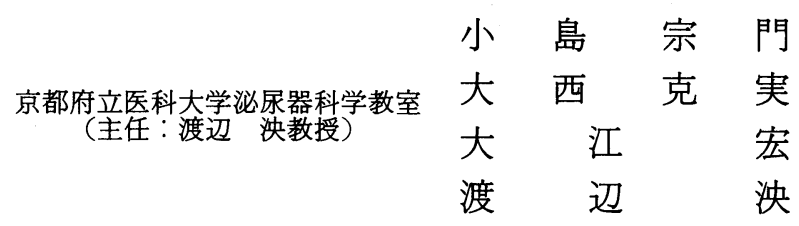

\section{TRANSRECTAL ULTRASONOTOMOGRAPHY AND URETHRAL PESSURE PROFILE IN BENIGN PROSTATIC HYPERTROPHY}

\author{
Munekado Kojima, Katsumi Ohnishi, Hiroshi Ohe and Hiroki Watanabe \\ Department of Urology, Kyoto Prefectural University of Medicine
}

(Director: Prof. H. Watanabe)

Urodynamic evaluation in benign prostatic hypertrophy $(\mathrm{BPH})$ was performed through a comparative analysis of transrectal ultrasonotomography and urethral pressure profile (UPP).

Ultrasonically calculated weight, presumed circle area ratio (PCAR) of prostatic adenoma, functional profile length (FPL) and Area in BPH patients complaining of urinary retention were all significantly larger than those in non-retention cases. Above all, Area showed the most prominent difference between these two patient groups. A significant correlation was also proved between PCAR and FPL, PCAR and Area, and FPL and Area.

A UPP pattern with pressure peaks at the prostatic region besides the external sphincter was recognized in a few cases. It was supposed that this double peak type of UPP could be recorded as a result of disturbance of the urethral pressure gradient (UPG), a new concept proposed in the current study, evoked by some uropathic factors.

The data presented here suggest that the combination of the transrectal ultrasonotomography and UPP would provide both morphorogical and functional informations to clarify the pathogenesis of urinary obstruction in $\mathrm{BPH}$.

要旨：前立腺肥大症患者（非尿閉群15例，尿閉群 5 例）に対して経直腸的超音波断層法ならびに尿道内 圧曲線を行い, その結果について尿水力学的に比較検討した.

1. 前立腺推定重量, 仮想円面積比, 機能的尿道長, 曲線下面積 (Area)はいずれも尿閉群症例が非尿 閉群症例に比べ有意に高い值を示したが，最高尿道内圧には差がなかった。

2. 仮想円面積比と機能的尿道長，仮想円面積比と Area，および機能的尿道長と Area，との間には有 意な相関関係が証明された。

3. 尿道内圧曲線を 1 峰型, 2 峰型の 2 つに分類した結果，大部分の症例では 1 峰型であったが，尿閉 群 2 例, 非尿閉群 1 例において 2 峰型の尿道内圧曲線が認められた。

4. 以上の結果について考察を加兄，仮想円面積比が尿道内圧の状態をよく反映すること，また尿道内 圧の総和である Area なるパラメーターが排尿障害の程度を最もよく示すことが明らかになった。ささら に尿道内圧勾配（UPG）といら新しい概念を用いて尿道内圧曲線を検討した結果，一部の症例に扣いて 観察された 2 峰型内圧曲線はUPG の乱れといった後部尿道の力学的変化の反映と考えられた.今後, 尿 道機能を考学るら壳でUPG なる新たな尿水力学的評価が必要であると考劣られた。 


\section{緒 言}

蓄尿および排尿機構の解明がすすむにつれ，膀胼内 尿道口より外尿道括約筋にいたる後部尿道の機能的重 要性が認識されつつある。

男性の場合, 後部尿道はほぼ全長にわたってその周 囲を前立腺によってとり囲まれている。したがって， 前立線癌, 前立腺肥大症, 前立線炎などの前立腺疾患 時には，後部尿道にも何らかの変化が生ずるものと考 えられ，これまでにも主に形態学的側面より検討が加 えられてきた. 従来, 後部尿道に対する検索の方法と してはもっぱら尿道鏡ならびに尿道造影が用いられて きたが，それらは後部尿道の形態学的変化の追求を目 的としたものであり，機能的検查法としては不十分な ものである。
Brown and Wickham (1969) ${ }^{1)}$ とり開発された尿 道内圧曲線 (Urethral Pressure Profile, UPP) は, 下部尿路に対する尿水力学的評価の手段のひとつとし て現在広く普及しており，とくに下部尿路通過障害を 有する患者では後部尿道の機能的検査として必須なる のになりつつあって, その有用性に関する報告も数多 くみることができる。一方，前立腺に対する経直腸的 超音波断層法 (渡辺ら, 1968) ${ }^{2}$ は, 前立腺の形態を非 観血的かつ客観的に知るうえで極めてすぐれたもので あり，超音波断層像の分析により前立腺の大きさと形 状について豊富な情報を得ることが可能である。

男性後部尿道ではその解剖学的位置関係より, 尿道 内圧曲線と前立腺超音波断層像との間に高い関連性が あることは容易に推測されるが，後部尿道をこの両者

Table 1 Results obtained from transrectal ultrasonotomography and urethral pressure profile (UPP) in 20 patients with benign prostatic hypertrophy. RU : residual urine, PW : weight of prostate measured ultrasonically, PCAR: presumed circle area ratio, FPL : functional profile length, UPmax : maximum urethral pressure, SP : single peak type, DP : double peak type

\begin{tabular}{|c|c|c|c|c|c|c|c|c|}
\hline \multirow{2}{*}{$\begin{array}{l}\text { Case } \\
\text { Number }\end{array}$} & \multirow{2}{*}{ Age } & \multirow{2}{*}{ R U } & \multicolumn{2}{|c|}{$\begin{array}{l}\text { Ultrasono- } \\
\text { tomography }\end{array}$} & \multicolumn{4}{|c|}{$U P P$} \\
\hline & & & $\begin{array}{l}P \text { W } \\
(g)\end{array}$ & $P C A R$ & $\begin{array}{l}F P L \\
(\mathrm{~cm})\end{array}$ & $\begin{array}{l}\text { U Pmax } \\
\left(\mathrm{CmH}_{2} \mathrm{O}\right)\end{array}$ & $\begin{array}{l}\text { Area } \\
\left(\mathrm{cm}^{2}\right)\end{array}$ & Type \\
\hline 1 & 59 & 6 & 23.2 & 0.63 & 3.5 & 97 & 15.1 & $\mathrm{SP}$ \\
\hline 2 & 59 & 10 & 16.3 & 0.74 & 3.1 & 86 & 9.7 & $\mathrm{SP}$ \\
\hline 3 & 66 & 10 & 28.8 & 0.84 & 3.6 & 80 & 17.8 & $\mathrm{SP}$ \\
\hline 4 & 62 & 8 & 55.3 & 0.86 & 2.7 & 84 & 8.5 & $\mathrm{SP}$ \\
\hline 5 & 78 & 35 & 20.8 & 0.60 & 2.5 & 55 & 6.9 & $\mathrm{SP}$ \\
\hline 6 & 66 & 30 & 26.4 & 0.78 & 4.9 & 100 & 20.3 & $\mathrm{SP}$ \\
\hline 7 & 75 & 5 & 31.6 & 0.62 & 1.4 & 63 & 5.2 & SP \\
\hline 8 & 61 & 13 & 26.4 & 0.85 & 2.7 & 104 & 7.6 & SP \\
\hline 9 & 73 & 4 & 28.5 & 0.79 & 4.3 & 81 & 19.4 & $\mathrm{DP}$ \\
\hline 10 & 69 & 35 & 22.5 & 0.75 & 4.8 & 73 & 16.6 & SP \\
\hline 11 & 74 & 20 & 18.8 & 0.87 & 5.5 & 80 & 22.4 & $\mathrm{SP}$ \\
\hline 12 & 51 & 20 & 18.4 & 0.82 & 1.7 & 48 & 4.6 & SP \\
\hline 13 & 67 & 23 & 26.7 & 0.78 & 3.9 & 110 & 20.0 & $\mathrm{SP}$ \\
\hline 14 & 50 & 0 & 28.5 & 0.83 & 4.3 & 98 & 20.1 & $\mathrm{SP}$ \\
\hline 15 & 69 & 0 & 20.4 & 0.72 & 3.3 & 75 & 12.0 & SP \\
\hline 16 & 63 & $\begin{array}{r}\text { Reten- } \\
\text { tion }\end{array}$ & 54.6 & 0.86 & 6.0 & 82 & 27.3 & SP \\
\hline 17 & 69 & $\begin{array}{r}\text { Reten- } \\
\text { tion }\end{array}$ & 27.8 & 0.84 & 3.9 & 106 & 25.7 & SP \\
\hline 18 & 69 & $\begin{array}{r}\text { Reten- } \\
\text { tion }\end{array}$ & 33.2 & 0.87 & 5.0 & 83 & 30.2 & DP \\
\hline 19 & 80 & $\begin{array}{r}\text { Reten- } \\
\text { tion }\end{array}$ & 47.7 & 0.92 & 6.6 & 68 & 32.3 & DP \\
\hline 20 & 80 & $\begin{array}{r}\text { Reten- } \\
\text { tion }\end{array}$ & 28.4 & 0.88 & 5.8 & 108 & 22.5 & SP \\
\hline Mean & 67 & & 29.22 & 0.793 & 3.97 & 84.1 & 17.21 & \\
\hline $\begin{array}{l}\text { Standard } \\
\text { Deviation }\end{array}$ & 8.51 & . & 11.01 & 0.091 & 1.42 & 17.5 & 8.34 & \\
\hline
\end{tabular}


の検査法を用いて機能的・形態学的側面より総合的に 評価した報告はいまだみられない。

われわれの教室では，排尿障害を訴える男性患者に 対して, 従来の検査に加兄, 経直腸的超音波断層法招 よび尿道内圧曲線による検討も合わせ行っている，本 報告では，前立腺肥大症例について超音波断層像と尿 道内圧曲線より得られた結果を比較検討し，前立腺肥 大症に抢ける両者の意義について論じるとともに，尿 道内圧曲線に関して興味ある所見を認めたのでそれに ついても言及する。

\section{対 象}

排尿困難を主訴として京都府立医科大学附属病院泌 尿器科外来を受診し, 臨床症状ならびに経直腸的超音 波断層法を含む泌尿器科学的検査により前立腺肥大症 と診断された男性患者のうち，20例を対象とした。 そ のらち 15 例は残尿量 $0 \sim 35 \mathrm{ml}$ の症例であったが, 残り の 5 例は尿閉を訴兄来院した患者であった，年齢は50 歳 80歳で, 平均年齢67歳であった（Table 1).

\section{方法}

\section{1. 経直腺的超音波断層法}

経直腸的走查専用装置（渡辺，1974）光用い，患者 を坐位の状態にして測定を行った．探触子を操作して $5 \mathrm{~mm}$ 扣さに前立腺水平断層像を $35 \mathrm{~mm}$ カメラで撮影 し，得られた前立腺断層像より Kontron-MOP システ ムを利用して各断面積を求め, 渡辺ら $(1975)^{4)}$ の方法 に従い前立腺推定重量を計算した。さらに各症例につ いて，最大断面積を示した超音波断層像から，大江ら $(1977)^{5)}$ により考案されたパラメーターである前立腺 仮想面円面積比 (Presumed Circle Area Ratio, PCAR）を算出した。

\section{2. 尿道内圧曲線}

患者を排尿後，仰臥位とし，キシロカインゼリーに て尿道粘膜表面麻酔を施したのち測定した，経尿道的 膀胱カテーテル留置例では，カテーテル拔去後少なく とも 3 時間以上経過してから検査を行った。 $12 \mathrm{~F}$ の尿 道内圧測定用カテーテルを尿道より膀胱内に挿入, 膀 胱を空虚にしたのち引き抜き装置 ${ }^{6}$ に接続して，1 1 分 間 $3 \mathrm{~cm}$ の速さで引き抜くとともに, 炭酸ガス内圧測定 器 (DISA21G45)を用いて 1 分間 $10 \mathrm{ml}$ の炭酸ガスを注 入しつつ尿道内圧を測定し, その結果は水注圧 $\left(\mathrm{cm} \mathrm{H}_{2}\right.$ O）として記録し，同一症例につき少なくとも 2 回は測 定を行い，再現性のあることを確認した。

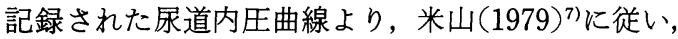
Fig. 1に示したごとく機能的尿道長 (Functional
Fig. 1 Schematic drawing of UPP illustrating the nomenclature used in the present study. FPL: functional profile length, UPmax: maximum urethral pressure

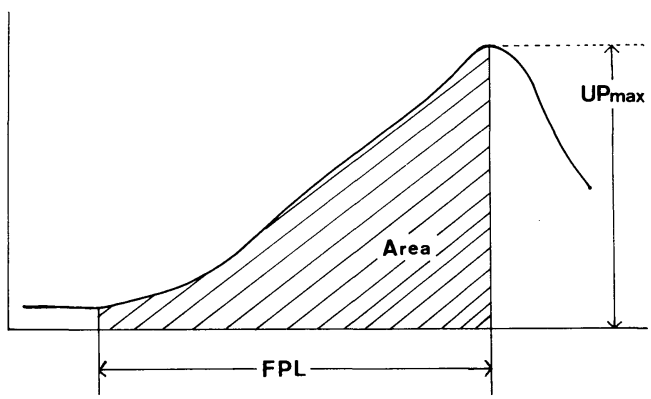

Profile Length, FPL), 最高尿道内圧 (maximum Urethral Pressure, UPmax)を求め, さらに KontronMOP システムを用いて FPL 間に打ける尿道内圧曲 線下の面積（Area）を算出した。

\section{結果}

前立腺超音波断層像および尿道内圧曲線より求めら れた。各症例に拈ける計測值を Table 1に示した。

1. 経直腸的超音波断層法

前立腺推定重量は $16.3 \mathrm{~g}$ (最小值) 55.3g（最大 値), 29.22 (平均値) \pm 11.01 (標準偏差) $\mathrm{g}$, 仮想円面

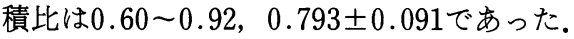

\section{2 . 尿道内圧曲線}

最高尿道内圧は $48 \sim 110 \mathrm{cmH}_{2} \mathrm{O}, \quad 84.1 \pm 17.5 \mathrm{cmH}_{2}$ $\mathrm{O}$, 機能的尿道長は $1.4 \sim 6.6 \mathrm{~cm}, 3.97 \pm 1.42 \mathrm{~cm}$, そし て曲線下面積（Area）は4.6 32.3 $\mathrm{cm}^{2}, 17.21 \pm 8.34$ $\mathrm{mc}^{2}$ であった.

つぎにこれらの結果を順次, 残尿量と比較検討した。 この場合，対象20例を非尿閉群（15例）と尿閉群（5 例）の 2 群にわけて対比し， $\mathrm{t}$ 分布検定を行った

Table 2 Mean values with standard deviations of ultrasonic and UPP parameters in BPH patient groups. PW: weight of prostate measured ultrasonically, PCAR: presumed circle area ratio, FPL : functional profiele length, UPmax : maximum urethral pressure

\begin{tabular}{|ll|c|c|}
\hline & non-Retention & Retention \\
\hline PW & $(\mathrm{g})$ & $26.17 \pm 9.23$ & $38.34 \pm 12.13$ \\
\hline PCAR & $0.765 \pm 0.089$ & $0.874 \pm 0.03$ \\
\hline FPL $(\mathrm{cm})$ & $3.48 \pm 1.17$ & $5.46 \pm 1.04$ \\
\hline UPmax $\left(\mathrm{cmH}_{2} \mathrm{O}\right)$ & $82.3 \pm 17.9$ & $89.4 \pm 17.1$ \\
\hline Area $\left(\mathrm{cm}^{2}\right)$ & $13.75 \pm 6.23$ & $27.60 \pm 3.83$ \\
\hline
\end{tabular}


Fig. 2 Values of weight of prostate measured ultrasonically (PW) in $\mathrm{BPH}$ patient groups. Difference between groups is significant $(p<$ 0.05). Each bar represents the mean value.

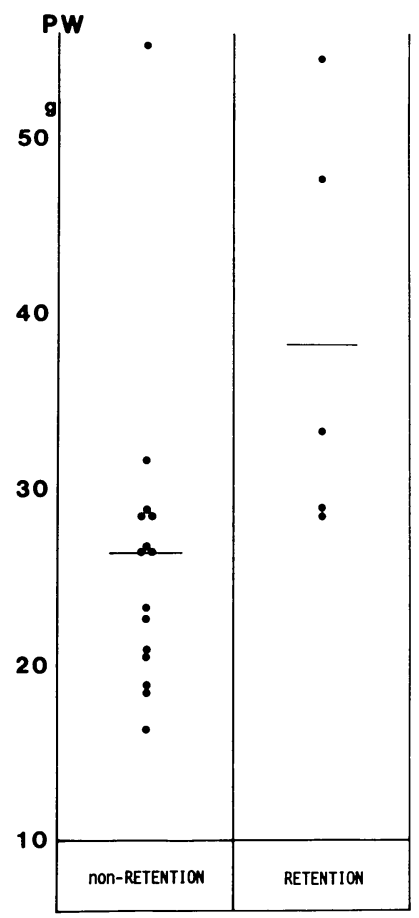

Fig. 3 Values of presumed circle area ratio (PCAR) in BPH patient groups. Difference between groups is significant $(p<0.05)$. Each bar represents the mean value.

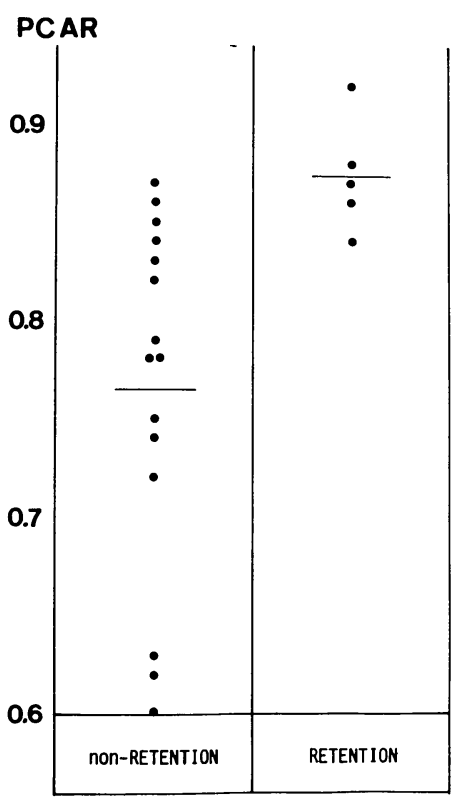

Fig. 4 Values of functional profile length (FPL) in BPH patient groups. Difference between groups is significant $(p<0.05)$.

Each bar represents the mean value.

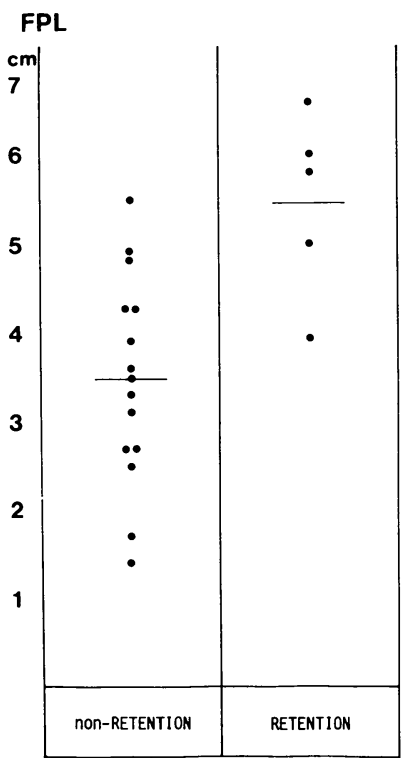

Fig. 5 Values of Area in BPH patient groups. Difference between groups is significant $(p<$ 0.05). Each bar represents the mean value.

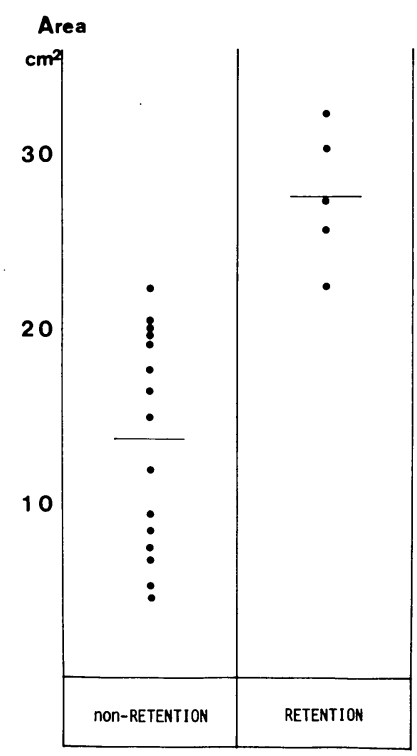


Table 3 Comparative analysis of correlation among ultrasonic and UPP parameters in BPH. Significant correlations are present between presumed circle area ratio (PCAR) and Area, PCAR and functional profile length (FPL), and FPL and Area. $\mathrm{p}<0.01$

\begin{tabular}{|c|c|c|c|c|}
\hline $\mathrm{X}$ & PW & PCAR & FPL & UPmax \\
\hline Axea & $\begin{array}{c}\mathrm{Y}=0.27 \mathrm{X}+9.46 \\
\mathrm{r}=0.35 \\
\mathrm{p}>0.05\end{array}$ & $\begin{array}{c}\mathrm{Y}=52.24 \mathrm{X}-24.22 \\
\mathrm{r}=0.57 \\
\mathrm{p}<0.01\end{array}$ & $\begin{array}{c}\mathrm{Y}=5.05 \mathrm{X}-2.84 \\
\mathrm{r}=0.86 \\
\mathrm{p}<0.01\end{array}$ & $\begin{array}{c}\mathrm{Y}=0.17 \mathrm{X}+3.18 \\
\mathrm{r}=0.35 \\
\mathrm{p}>0.05\end{array}$ \\
\hline UPmax & $\begin{array}{c}Y=0.05 X+82.7 \\
r=0.03 \\
p>0.05\end{array}$ & $\begin{array}{c}\mathrm{Y}=0.38 \mathrm{X}+83.80 \\
r=0.002 \\
\mathrm{p}>0.05\end{array}$ & $\begin{array}{c}Y=3.70 X+69.4 \\
r=0.3 \\
p>0.05\end{array}$ & \\
\hline FPL & $\begin{array}{c}\mathrm{Y}=0.04 \mathrm{X}+2.76 \\
\mathrm{r}=0.32 \\
\mathrm{p}>0.05\end{array}$ & $\begin{array}{c}\mathrm{Y}=8.74 \mathrm{X}-2.96 \\
\mathrm{r}=0.56 \\
\mathrm{p}<0.01\end{array}$ & & \\
\hline PCAR & $\begin{array}{c}\mathrm{Y}=0.003 \mathrm{X}+0.69 \\
\mathrm{r}=0.43 \\
\mathrm{p}>0.05\end{array}$ & & & \\
\hline
\end{tabular}

(Table 2).

上記 5 つの計測値のらち, 最高尿道内圧を除く残り の 4 つのパラメーター, すなわち前立腺推定重量 (Fig. 2), 仮想円面積比 (Fig. 3)，機能的尿道長 (Fig. 4) そして曲線下面積 (Area, Fig. 5) は，いずれも尿閉群 に招いて非尿閉群に比べ有意に高い值を示した（ $\mathrm{p}<$ 0.05). とくに曲線下面積 (Area) は, 非尿閉群の最大

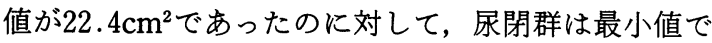
も22.5 $\mathrm{cm}^{2}$ あ，その差は歴然であった。

さらに，前立腺超音波断層像拈よび尿道内圧曲線よ

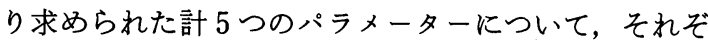
れの計測值間の相関関係の有無を調べる目的で，合計 10通りの組み合わせについて相関係数ならびに回帰直 線を求め，その有意性について検定（ $\mathrm{t}$ 分布検定）を 行った (Table 3).

前立腺推定重量は他のいずれのパラメーターとも有 意な相関を示さなかった。仮想円面積比は，機能的尿 道長（Fig. 6）および曲線下面積 (Area, Fig, 7) との 間で有意な相関関係にあった $(\mathrm{p}<0.01)$ ，機能的尿道 長と曲線下面積 (Area) との間には，相関係数 0.86 と 最も良好な相関が認められた $(\mathrm{p}<0.01$, Fig. 8). 以上 3 つの組み合わせ以外では，いずれす相関係数が 0.43 以下であり，有意な相関関係を証明することはできな かった。

最後に, 尿道内圧曲線の記録波形そのものを各症例 について比較検討したところ，内圧曲線はその波形パ

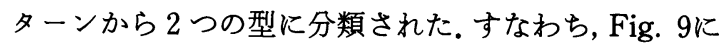
みられるごとく，尿道内圧曲線が膀胱内尿道口より前 立腺部に向かってなだらかな上昇カーブを描き，外括 約筋部で最高尿道内圧を示したのち急激に下降すると
Fig. 6 Correlation between functional profile length (FPL) and presumed circle area ratio $(\mathrm{PCAR})$ in $\mathrm{BPH}$ patients. $\mathrm{Y}=8.74 \mathrm{X}-2.96, \mathrm{r}=$ $0.56, \mathrm{p}<0.01$

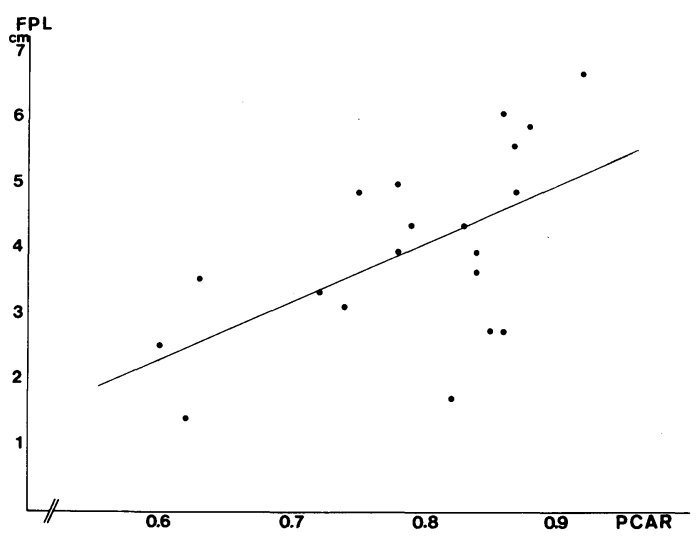

いった 1 峰性の比較的単純な曲線波形と, Fig. 10にみ られるごとく，内圧曲線が前立腺部で一過性の内圧上 昇を示したのち再び外括約筋部で最高尿道内圧にいた るといった 2 峰性の複雑な波形の， 2 種類の尿道内圧 曲線である. そこでわれわれは, 前者を 1 峰型(Single Peak or SP Type), 後者を 2 峰型 (Double Peak or DP Type）と名づけた。このように記録された尿道内 圧曲線を 1 峰型. 2 峰型のいずれかに分類した場合, 非尿閉群ではほほ全例（15例中14例）において 1 峰型 であり， 2 峰型を示したのは 1 例にすぎなかった。そ れに対して尿閉群では 5 例中 3 例が 1 峰型, 2 例が 2 峰型であり 2 峰型が比較的多くみられた。

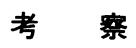

渡辺ら (1968) 2)により実用化された経直腸的超音波 
Fig. 7 Correlation between Area and presumed circle area ratio (PCAR). $\mathrm{Y}=52.24 \mathrm{X}-24.22, \mathrm{r}=$ $0.57, \mathrm{p}<0.01$

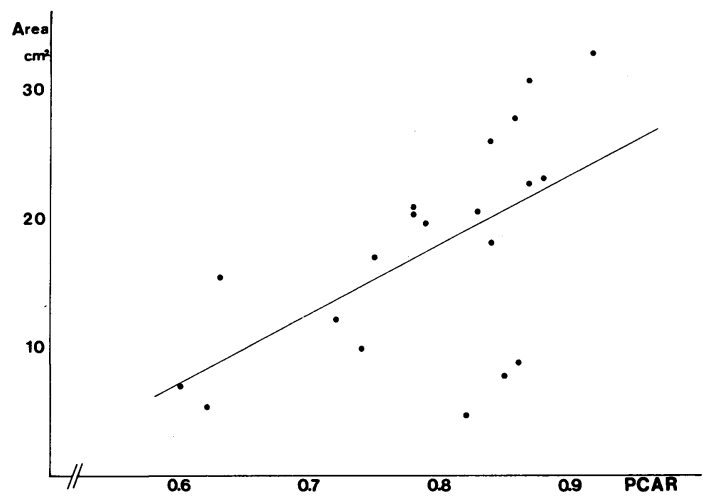

Fig. 8 Correlation between Area and functional profile length (FPL). $\mathrm{Y}=5.05 \mathrm{X}-2.84, \mathrm{r}=0.86$, $\mathrm{p}<0.01$

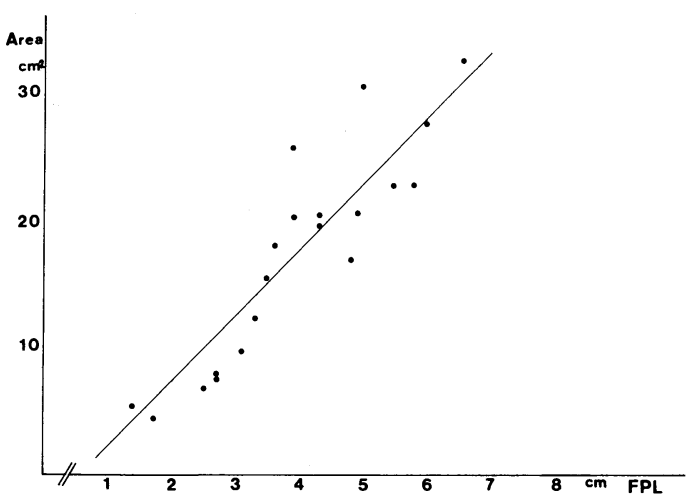

Fig. 9 Urethral pressure profile of single peak type found in case number 8 . A peak of urethral pressure is recorded at the region of external urethral sphincter.

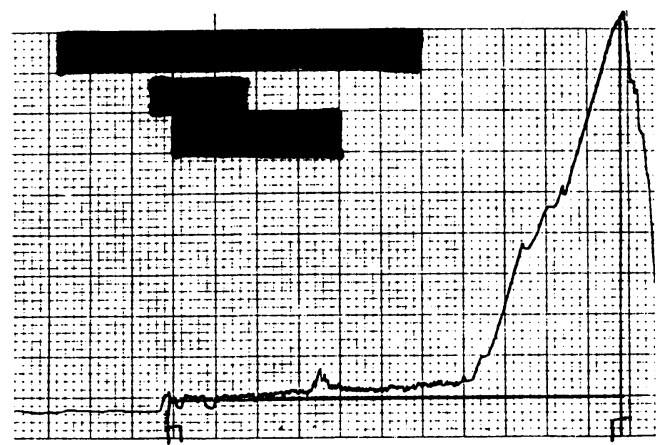

Fig. 10 Urethral pressure profile of double peak type found in case number 18 . Note the pressure peaks at the prostatic region besides at the external urethral sphincter.

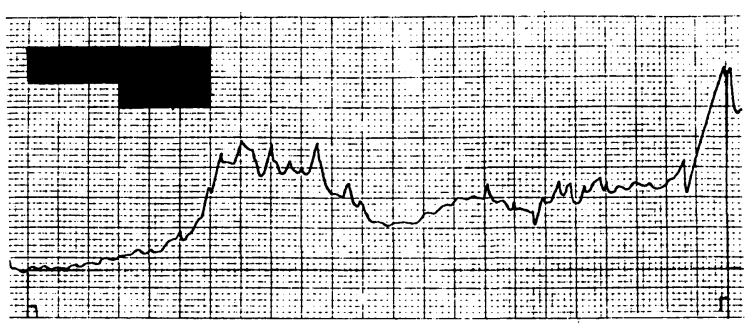

断層法は, 骨盤腔内臟器のひとつである前立腺の大き さと形状を，客観的かつ正確に把握できる非観血的検 查法として極めて有用なるのである。近年におけるそ の臨床応用は，前立腺疾患の診断・治療を画期的に進 歩せしめた。経直腸的超音波断層法により前立腺癌, 前立腺肥大症などの早期発見が可能となり，さらにそ れらに対する各種治療の効果判定も容易に行らことが できるようになった ${ }^{8)}$.最近では，その簡便さゆえに前 立腺集団検診にも応用され，多くの成果を挙げてい $3^{9)}$.

前立腺肥大症 $(\mathrm{BPH})$ に拈ける超音波水平面断層像 は，断面の払大を示すとともに，前立腺の腫脹につれ て半月形から円形に近い形状を呈するょうになる。前 立腺超音波断層像より求められるパラメーターのひと つに前立線推定重量があるが，その值は実際の摘出前 立腺重量とよく相関することが知られている(4)10).斉 藤ら $(1977)^{11)}$ は, 前立腺推定重量が33g 以下の症例で は尿閉がおこりにくいことを報告しているが，われわ れの結果でも，尿閉群症例の前立腺推定重量は非尿閉 群に比べ有意に高い值を示した。すなわち，尿閉発生 のためには前立腺の重量増加が必要条件のひとつに なっていると考えられる。

前立腺超音波水平面断層像の形状が，前立腺の肥大 の程度によって半月形から円形へと変形することはす でに述べたが，その変形の度合を具体的に数值で表し たのが仮想円面積比(PCAR)である(大江ら，19775)）。 経直腸的超音波断層法により得られた前立腺断面が， どの程度円形に近いかを表現するのが PCAR であり， PCAR が1.0に近づくほどその断面は円形に似ること になる，前立腺肥大症は内腺が腫大する疾患であるか ら，その肥大につれて腺腫は被膜により圧縮され，そ の結果前立腺は緊満状態でもって膨張することにな り，超音波断層面は次第に円形に近い形状を呈するよ 
らになる。したがって，PCAR は前立腺の大きさその ものではなく，前立腺自体の形状変化を示すものであ る. PCAR が前立腺の肥大による緊満度を示している とすれば，PCARが高い場合には，尿道は周囲の前立 腺より強い圧迫を受けその尿道内圧は上昇するはずで ある。この尿道内圧の上昇は前立腺による機械的影響 によるものであるから，排尿時の尿道抵抗の増大にな り排尿障害をきたすことになる。

大江ら $(1977)^{5)}$ は残尿量と PCAR の関係につき多 数例について検討を行った結果. PCAR が 0.75 以下で はほとんどの症例が残尿 $30 \mathrm{ml}$ 以下であり，0.75を越兄 ると突然, 残尿の著明な増加が始まり，とくに尿閉は 0.75 以上にのみ認められたと報告している。われわれ の症例でも, PCAR と前立腺推定重量との間には何ら 相関関係は認めなかったが, 尿閉群における PCARは 非尿閉群に比べ有意に高く,すべて 0.84 以上であった。 一方, 非尿閉群のなかにも PCAR の高い症例があった が，それらは常に尿閉の危険性をはらんだ患者である のかもしれない，後でも述べるように，仮想円面積比 (PCAR)なる概念は，前立腺肥大症に打ける排尿障害 の病態を解明するうえで，重要な足がかりになるもの と思われる。

尿道内圧曲線（UPP）は，後部尿道の静止状態にお ける内圧を記録したものである，男性の場合には，後 部尿道がほぼ完全に前立腺にとり囲まれているので， 尿道内圧が前立腺の影響を強く受けていることは極め て当然であると考兄られる.とくに前立腺肥大症では, 前立腺の腫脹・増大といった形態学的変化に伴って尿 道内圧も変化することは容易に推察される。

尿道内圧曲線より求められるパラメーターとして は, 一般に, 機能的尿道長 (FPL) と最高尿道内圧 （UPmax）が用いられることが多い，前立腺肥大症例 に打けるこの両者の变化についてはこれまでにも諸家 の報告がみられ，その多くはFPLの延長を指摘して (る ${ }^{7122}$. また前立腺肥大症に対する外科的被膜下摘

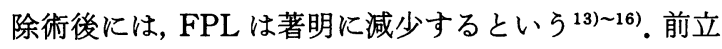
腺肥大症の場合, 前立腺の肥大につれ後部尿道, すな わち前立腺部尿道の長さ（FPL）が延長することは予 想されるところであり, Kondo et al. (1979) ${ }^{17)}$, 森田 ら $(1981)^{18)}$ は, FPL と摘除前立腺重量との間に強い相 関関係を認めている。しかし Rao et al. (1979) ${ }^{15)}$ は, この両者の間には有意な相関はなかったと報告してい る。われわれの結果でも，FPLは超音波断層像より計 算された前立腺推定重量との間に，有意な相関を示さ
なかった。これらは, 前立腺の肥大が常に前立腺部尿 道の延長を伴うものではないことを物語っている。

最高尿道内圧（UP max）は，前立腺肥大症に损い ても正常例と比べ変化が少ないとする報告が多い，今 回の研究でも, UPmax は他のいずれのパラメーター とも有意な相関を示さなかった，UPmax は尿道内圧 曲線上, 外尿道括約筋部に一致して記録され, 前立腺 というよりむしろ外括約筋のトーヌスを反映している ものと考えられる。

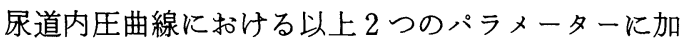
え, 米山 $(1979)^{7)}$, Kondo et al. (1979) ${ }^{17)}$ は新たに Area なる診断基準を追加した. Area は FPL に相当する部 分の尿道内圧曲線下の面積を求めたものであり，前立 腺部尿道の内圧の総和に一致する。米山 $(1979)^{7)} に よ$ れば, Area は正常例に比べ前立腺肥大症で著明に増 大するという。また Kondo et al. (1979) ${ }^{171}$ は，前立腺 肥大症の摘出前立腺重量が Area とょく相関すると報 告している。われわれの場合に扔いても，尿閉群の Areaはすべて $22.5 \mathrm{~cm}^{2}$ 以上であったのに対し，非尿 閉群のそれは4.6〜22.4 $\mathrm{cm}^{2}$ と有意な差があり, Area なるパラメーターが排尿障害の状態をよく反映してい ると考えられた。

また，Area が FPL とともに，PCAR とも高い相関 性を示したのは興味ある事実である。Area なる計測 值が，長さと内圧の 2 つの要素より成り立っている以 上，それが FPL とよく相関するのは当然であろう。し かしながら PCAR とも有意な相関関係にあったとい らことは, PCARが尿道内圧をよく反映していること の証明と思われる。すなわち, PCARが高いといらこ とは，尿道内圧も同時に上昇していることは意味し， その結果内圧曲線を押し上げ Area が増大するわけで ある. Area，すなわち総尿道内圧は，理論的には静止 時のものであるが, 前立腺肥大症に秃いてはその増大 は前立腺の肥大といら機械的原因によるものであるか ら, 当然排尿時には前立腺部尿道抵抗として排尿障害 を惹き起こすことになる．ゆえに，前立腺肥大症に拉 ける排尿障害の原因を前立腺の大きさの増大にのみ求 めるのではなく, 前立腺の肥大に伴ら形態の変化にも その病因があることを,はっきりと認識すべきである.

最後に, 前立腺肥大症患者の尿道内圧曲線上り得ら れた興味ある所見について述べることにする，尿道内 圧曲線は一般に, 膀胱内尿道口ょり引き抜かれるにつ れてその波形は徐々に上昇し，外尿道括約筋部で最高 に達し，それ以降は急激に下降するといった，比較的 
なめらかな 1 峰性の波形を描くとされている。そして 得られた記録曲線より, FPL, UP max, Area といっ たパラメーターを求め, それらをもとにして検討が加 えられることになる，たしかにわれわれの症例でも大 多数の場合には, 上記のような典型的な尿道内圧曲線 が記録され，われわれはそのような内圧曲線を 1 峰型 と分類した。しかし，一部の患者ではそれとは異なっ た波形パターンを有する内圧曲線が認められた。すな わち, 内圧曲線が前立腺部で一過性の上昇カーブを描 いたのち, 外尿道括約筋部で再び最高值に達すると いった． 2 峰性の複雑な曲線が記録されたのである. そしてわれわれは, この種の内圧曲線を 2 峰性型とし て，前者の 1 峰型波形パターンから区別した.

Abrams (1976) ${ }^{19)}$, 前立腺部でみられる 1 峰性の内 圧上昇をProstatic Peak として注目し，そのPeak は 45歳以下の尿道抵抗の比較的小さい症例では出現せ ず，また FPL が $5 \mathrm{~cm}$ 以下の場合にも観察されなかっ たと述べている。われわれが 2 峰型の内圧曲線を認め 得た 3 例のらち 2 例は尿閉群の症例であり，それらの FPLはいずれも延長していた。これらのことより，尿 道内圧曲線を解析するら爷で, FPL, UPmax, Area と いった従来からのパラメーターに加光, 先に述べたご とく記録波形そのものを考慮した新たな診断基準が必 要であると考えられる.

ここでわれわれは，尿道内圧曲線の波形パターンを 分析するらえで, 尿道内圧勾配 (Urethral Pressure Gradient, 以下 UPG と略す) なる新たな概念を提案し たい.

UPG とは尿道内圧曲線の微分値のことであり, $\mathrm{UPG}=\frac{\Delta \mathrm{P}}{\Delta \mathrm{L}}$ の式で表されることになる (Fig. 11).こ の值は 1 峰型の内圧曲線の場合には, 膀胱頝部より UPmaxを示す外尿道括約筋部にいたる後部尿道

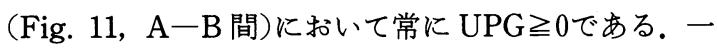
方, 2 峰性型の場合には, Fig. 12に示すように A-B

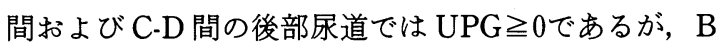
一C間においては，他の部位と異なり $\mathrm{UPG} \leqq 0$ となっ ていることになる.すなわち， 2 峰型内圧曲線では後 部尿道の一部に招いて UPG が逆転しているわけであ る. その意味において, 2 峰型内圧曲線を示す後部尿 道は，1峰型のそれに比べ異なった力学的環境下にあ ることになる。

正常状態の静止時後部尿道が UPG $\geqq 0$ 状態にある ことは, 生理学的に極めて合理的である。なぜなら,
Fig. 11 Schematic drawing of UPP pattern of single peak type with illustration of urethral pressure gradient (UPG). UPP recorded between bladder neck (A) and external urethral sphincter (B) always indicates a positive value of UPG. L : urethral length, $\mathrm{P}$ : urethral pressure

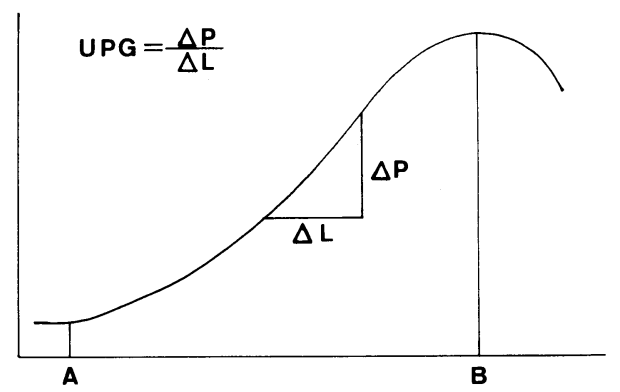

Fig. 12 Schematic drawing of UPP pattern of double peak type. Pressure peaks are fund at the prostatic region (B) and at the external urethral sphincter (D). UPG between A-B and C-D indicates a positive value. while that between $\mathrm{B}-\mathrm{C}$ indicates a negative value.

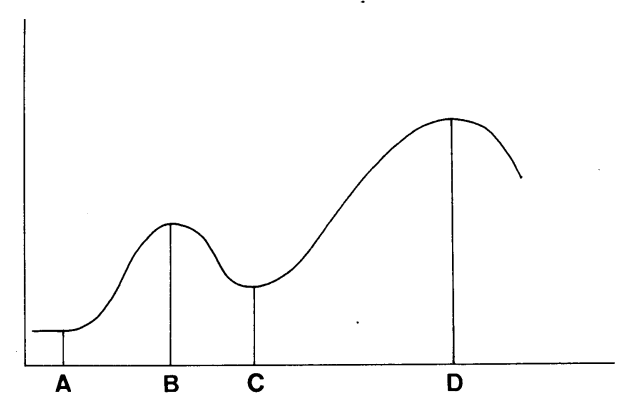

尿道分泌物を尿道内にうっ滞さすことなく円滑に膀腅 内へ流入させるためには, 前立腺部尿道の内圧がいか なる部位でも遠位側より近位側が低い状態, 言いかえ れば, UPG が後部尿道に扔いて常に正であるといら尿 水力学的条件が必要になると考学られるからである. 万一, 後部尿道の UPG が何らかの原因で乱れ部分的 に負の状態になれば, その部位で尿道分泌物のうっ積 が生じることになり, 前立腺・精のうなどの隣接蔵器 に二次的病変を招くものと想像される.

本研究に打いてわれわれは, 尿道内圧曲線がその波 形パターンにより 1 峰型あるいは 2 峰型のいずれかに 分類されることを述べたが，尿水力学的見地よりそれ ら 2 つの型の内圧曲線をとらえた場合, その最も重大 な相違点は先に説明したごとく, 後部尿道において UPG が乱れているかどらかである.すなわち，1峰型 
においてはUPG が常に正であるのに対して，2 峰型 ではその一部分において UPG が逆転し，乱れている のである.このようなUPGの乱れを伴った尿道内圧 曲線が尿閉群に比較的多く認められた原因は，今後検 討されるべき課題である.

これまでに多くの研究者が後部尿道を対象として取 り上げてきたが，UPG といった概念でもって検討を 行った報告はみられない.UPG といら新しい尿水力学 的診断基準を用いることにより，新たな観点に立った 前立腺・精のう疾患の病態解明の可能性がある。

\section{文献}

1) Brown, M.B. and Wickham, J.E.A.: The urethral pressure profile. Brit. J. Urol., 41, 211-217, 1969.

2）渡辺 決, 加藤弘彰, 加藤哲郎, 森田昌良, 田中元 直, 寺沢良夫：超音波断層法による前立腺診断.日 泌尿会誌，59，273-279，1968.

3）渡辺 決：類直腸的超音波断層法の開発と応用. 日泌尿会誌，65，613-632，1974。

4) 渡辺 決, 猪狩大陸, 海法裕男, 棚橋善克, 原田一 哉, 斉藤雅人：超音波断層法による前立腺計測. 西 日泌尿，37，222-232，1975.

5）大江 宏, 斉藤雅人, 田中重喜, 板倉康啓, 渡辺泱： 前立腺肥大症の超音波診断. (第 2 報) 前立腺肥大 症の成り立ちと仮想円面積比. 日超医論文集, $32-61,121-122,1977$.

6）近藤厚生 : 下太尿路の尿流動態研究. III. 尿道内圧 形測定器の試作とその臨床所見. 日泌尿会誌, 69, 23-32, 1978.

7) 米山威山：積分器導入による Urethral pressure profileの定量化の試み.日泌尿会誌, 70, 386 -391, 1979.

8）三品輝男, 渡辺 泱, 大江 宏: 経直腸的超音波断 層法による前立腺癌治療効果の monitoring. 癌の 臨床, 25, 878-883, 1979.

9）渡辺 決, 三品輝男, 大江 宏, 斉藤雅人：前立腺 の集団検診。日本医事新報，2830，28-31，1978.

10) Watanabe, H., Igari, D., Tanahashi, Y., Harada, K. and Saitoh, M.: Transrectal ultrasono- tomography of the prostate. J. Urol., 114, $734-739,1975$.

11) 斉藤雅人, 森 康行, 田中重喜, 大江 宏, 渡辺 決：前立腺肥大症の超音波診断.（第 1 報）前立腺 の大きさと残尿量. 日超医論文集, 31-115, 229-230, 1977.

12）丸彰夫: 尿道内王曲線 (Urethral Pressure Profile)の臨床的研究(第一報). 日泌尿会誌, 65, 506-519, 1974.

13) Anderson, J.T., Bourne, R.B. and Bradley, W. E. : Combined electromyography and gas urethral pressure profilometry before and after transurthral resection of the prostate. J. Urol., $116,622-625,1976$.

14）南 光二, 永井信夫, 金子茂男, 井口正典, 郡健二 郎, 門脇照雄, 秋山隆弘, 八竹 直, 栗田 孝: 排 尿津構にかんする検討. 第 3 報 urethral pressure profile の臨床的意義について。 日泌尿会誌, 69, 93-99, 1978.

15) Rao, M.M., Evans, R.R.C. and Marshall, V.R. : The effect of prostatectomy onurodynamic parameters. Brit. J. Urol., 51, 295-299, 1979.

16）森田 勝, 吉岡 進, 岡本正紀, 別宮 徹, 越知憲 治, 竹内正文：排屑機構に関する臨床的検討. 第 2 報. 成人男子下部尿路通過障害での Urethral pressure profile-volume change $と$ postural change に関して. 西日泌尿, 43, 41-46, 1981.

17) Kondo, A., Narita, H., Otani, T., Takita, T., Kobayashi, M. and Mitsuya, H.: Weight estimation of benign prostatic adenoma with urethral pressure profile. Brit. J. Urol., 51, 290-294, 1979.

18）森田 勝, 吉岡 進, 岡本正紀, 別宮 徹, 越知憲 治, 竹内正文：排尿機構に関する臨床的検討. 第 3 報. 前立腺肥大症に対する臨床的検討. 西日泌尿, 43, 47-52, 1981.

19) Abrams, P.H.: Spincterometry in the diagnosis of male bladder outflow obstruction. J. Urol., 116, 489-492, 1976.

（1983年12月 3 日受付） 